\title{
Kinds of the Attribute in the Mari Language
}

\author{
Galina L. Sokolova ${ }^{1}$, Elena L. Yandakova ${ }^{1} \&$ Andrej V. Richkov ${ }^{1}$ \\ ${ }^{1}$ Mari State University, Yoshkar-Ola, Russia \\ Correspondence: Galina L. Sokolova, the Mari State University, Lenin Street 1, Yoshkar-Ola, Mari-El 424001, \\ Russia.
}

\author{
Received: February 21, 2015 Accepted: March 15, 2015 Online Published: April 29, 2015 \\ doi:10.5539/res.v7n8p88 URL: http://dx.doi.org/10.5539/res.v7n8p88
}

\begin{abstract}
This article is devoted to research of the kinds of the attribute in the Mari language. According to the different features five kinds of the attribute are distinguished. They are expanded and not expanded; isolated and not isolated; prepositive and post-positive; coordinated and uncoordinated; homogeneous and inhomogeneous. In the Mari language attributes can be subject to semantically equal and unequal dependent words in the same or different morphological forms. Separation of the Mari attributes occurs in the case of postposition and there is also its coordination with the determining word. In the Mari language determining of the postpositional attributes is associated with emotional coloring of speech. During the research it was found that the preposition and postposition of the attribute characterize them as uncoordinated and coordinated. The homogeneous attributes are different from inhomogeneous ones in that they are connected with coordinative bond and they exercise identical syntax functions and characterize person or object on the different sides. All these kinds of the attributes give the most complete picture of parts of the sentence in the Mari language.
\end{abstract}

Keywords: attribute, kinds, features, isolation, position, coordination, expansion, homogeneity

\section{Introduction}

Between the attribute and the determinedword there is an attributive relationship in the Mari language. The attribute is used before a noun or a substantivized word in the most cases in the Mari language and the order of the components is based on the model as "the attribute+the determined word". The attribute points to the quality and properties of persons and objects, features of objects in time, position, quantity, attachment and their relation to other subjects.

According to their significance following attributes are distinguished in the Mari Language as: 1) qualitative attributes which show color, taste, size, shape, material of the object; 2) attributes whish express attachment; 3) attributes which characterize subject according to its relation to another subject; 4) attributes which define quantity of the determined word.

In the Mai language the rule of combinability of words are various. Attributes, which comprise attributive word combination, are members of its subordinates and they are combined with the subject, object, adverbial modifier, or nominal part of the predicate.

The syntax group of the attributive word combination includes noun, adjective, numeral, pronoun, participle, infinitive and imitative word as an attribute.

\section{Materials and Methods}

The aim of this study is to consider the kinds of attributes in the Mari language. As the factual materials of research the original works of classical and contemporary Mari prose, poetry, drama and press are investigated. Theoretical and methodological base was papers of the Finno-Ugric and Russian linguistics. During examining of the attribute method of synchronic description of the collected material with using of distributive analysis and elements of diachronic method were applied.

\section{Results}

In the Mari language, our analysis of the attribute allowed to divide it into five types according to the following criteria:

- According to using of the attribute it can be expanded or not expanded. 
- According to making different intonation it can be isolated and not isolated.

- According to position of the main word attribute can be prepositive and postpositive.

- According to coordination it can be coordinated and uncoordinated attribute with the determined component.

- According to having two or more identical or different morphological forms and meanings attribute can be homogeneous and inhomogeneous.

\subsection{Expanded and not Expanded Attributes}

In the Mari language there are more not expanded or single attributes, for example: "And there rye seedlings seem green, very green" (Oraj, 1978). "Travellingperson sees much" (Shabdar, 1975). "Another woman goes hanging her head and says nothing" (Savi, 1978). "The rich man had large field" (Columb, 1972). "Night's darkness covers everything, hides" (Shketan, 1991).

There are a lot of examples of using of expanded attributes: (Shketan, 1975). "His carefully grown son sits as an old man on a bench at the door"; (Oraj, 1978). "At the steps of the club short powerfully built young man stands"; (Shabdar, 1975); "At the foot of hills gathered people paused for a while" (Shabdar, 1975). "In the small, similar to a bath house of Yapyk'swifethere is little light" (Shabdar, 1975). "Near standing rural young man often shamelessly looked at her".

In the Mari language attributes can spread with semantically equal and unequal dependent words in the same or different morphological forms, for example: Shabdar, 1975. "In house People make noise like bees: they say about one another, laugh" (Oraj, 1978). "He fell in love with Marina, an orphan girl, living at the end of village Ozambay in the last house by the river" (Chavajn, 1981). "On the front wheel of the cabbies front star was broken".

\subsection{Isolated and not Isolated Attributes}

Secondary parts of the sentence can be isolated or not isolated. In the linguistics it is considered that..."Isolation is rhythmic and international distinguishing of any not main part of the sentence in order to inform the importance of non-independent communicative significance" (LES, 1990).

Isolation of the secondary parts of the sentence is affected by:

1) Parts of the sentence are expanded or not expanded, i. e. they receive more syntactic autonomy when there are more secondary parts of the sentence of explanation, and a reason for their isolation appears.

2) Order of the words, i. e. unusual order of the words, and the distancing determining word from determined is a cause of the isolation of the secondary parts of the sentence.

3) Clarifying meaning of one part of the sentence in relation to another one.

And every secondary part of the sentence has its individual way of isolation. The first feature of the isolation was formulated by A. M. Peshkovski. In his opinion the main condition is "interrelation of two parts which are not connected with syntactic link of the parts as relation of determining word to define one and particular to the general; interrelation of two members which are not connected with syntactic ties as determining word to determined one and general to the particular; order of the words; size of the isolated group; neighborhood of other isolated groups; special division of the group from the nearest member to which it can be joined and belong to a more remote one" (Peshkovski, 1956).

Isolation of the attribute emphasizes the sign, quantity of the subject and person with great power and strengthens their semantic role in the sentence. Isolated attribute gives adding information about the determined word, it revives the whole statement with the grammatical isolation.

Connection of the attribute with the determined word is weakened during the isolation. In the case of postposition to the main word the isolated attribute gets the meaning of predication a little and it is consistent with the determined word, for example: (Kugarnja, 2001). "Beautiful song enchants gentle spring.// Nature takes off its coat white". // Ямдылалтсародосемынвашлияш (Kazakov, 1968). "The first Soviet citizen visited from the earth (in space), // Be ready to meet as the relatives". // (Kazakov, 1951). "Plunges a knife poisoned // fascist gangs into the human heart".

In the Mari language isolated attributes can be expressed by:

1) Айдеме, пашашкушшо, илышынсаймогыржымпала (Timofeeva, 1989). "The man, who grew up at work knows the good side of life".

2) Adjectives, for example: Асатуммогайымкучет?-адакйодеш. Кресаньыкланэнкёлешсату- 
бакалейныйвеле",-манам (Shabdar, 1975). “And what goods do you have?”-He asks again. "Such goods which are the most necessary for peasants- grocery"; Шукертеогылиленкалык, // Пешаккугу, пешкуатле (Chavajn, 1980). "Not so long ago people lived, // Very large, very strong". Икписьмам, (ИванМаксимовичлан) ятыркугум, возыш (Chavajn, 1983). "He writes one very long letter (to Ivan Maksimovich)". Шӱмсаламым, энмоторым, // эняндарым, таченал! (Kazakov, 1968). "The warmest regards, the most beautiful, // The cleanest, you accept today!"

The difference of the isolated attributes and not isolated ones are defined by their meanings and functions of the sentences. Not isolated attributes distinguish sign of the object as it is and the isolated attribute gives us adding information about sign of the subject. Differences and syntactic functions of these two attributes are connected with attributive relations of not isolated attribute with clarified word and it has attributive functions and isolated attribute expresses signs of the predication.

\subsection{Prepositive and Postpositive Attributes}

In the Mari language we often can see preposition of the attribute. Position of the attribute before the determined word is considered as a norm in the Mari language and in the other Finno-Ugric languages. In the Mari language position of the attribute is generally accepted as prepositive according to the determined word and it does not depend on parts of the sentence of the attribute, for example: Каскечекенежымпешонай, пешяндар (Shketan, 1991). "In summer evening sun is very interesting and bright". Вакшамбаршӱкшемын (Shketan, 1991). "Mill barn became old". Кечекуэвуйымчевертеншинчеш (Shabdar, 1975). "The sun is setting, blushing tops of the birches". Пашадаржечумыржошӥдӧ тенгелектеш (Shabdar, 1975). "The salary is one hundredrubles in general".

We often meet the postpositive using of attribute in the poetic and in the folk poetic language in order to make statements more emotional colored and in order to distinguish any part of the sentence. It is possible to have postposition of the attribute which can be noun or pronoun, for example: Кӱслезе-тачатмарий ӱдырынчапшедалӱмжӧ, // Мастарлетыгайаклалтешэнпоянкузыклан (Columb, 1965) "Harps' player is a name and a fame of the Mari girl today// The mastery such is considered the best dowry".

Using of the attribute is also possible in the isolation in the postposition, for ехаmple: Могаесылнекундемем, пеледше! (Kugarnja, 2001). "How beautiful our region flourishing". Ончалешпасум, шурнаншым, // Узаводым, кӱшнӧлталтшым (Kazakov, 1951). "Look at the fields, wheaten // New plants, rising up".

\subsection{Coordinated and Uncoordinated Attributes}

In the Mari literal language the most attributes are uncoordinated. They take place in the preposition according to the main word and they are connected with nominal uncoordinated bond, for example: Опкынкатышкиндымкочкеш, коркавӱдымйӱэш (Chavajn, 1981). "An avid person eats a piece of bread, drinks a bucket of water"; МоторверыштеСемонкуванкугызажепӧртымыштен (Savi, 1978). "On the beautiful place husband of Semoniha built a house"; government, for example: Содормӧнгешсавырнен, рушлакапкапеленпызненшогале, тамаксигаркыжыматйолйымакшуыш (Сапаев, 1979). "Having turned quickly, he leaned as Russian on the gate, dropped a cigarette at his feet hastily". Тайылыштепортышгайсӧрем, верын-верыношмауло (Savi, 1978). "In the lowland there is virgin soil, as felt, there is sand on some places"; adjunction, for example: ...чаткаташыжымсомылшукоыле, шияшжапситеногыл (Sapaev, 1979). “... in the beautiful autumn there were a lot of works, there was no threshing time". Ўжмӧ уна-влакчылангаяктолыныт (Sapaev, 1979). "Invited guests came, it seems that all".

As we consider components of the attributive constructions with possessive relations of the word combinations or sentence are connected with incomplete (partial) coordination in the Mari language, for example: Тыймутымотколыштгын, мыйынэргымотыл,--маннеЭвай (Shketan, 1991). "If you do not listen to my words, you will not be my son, -Evaj said.” Тыйынпашат, ЗояИвановна, Тамарампеленналаш (Chavajn, 1981). "It is your business, Zoya Ivanovna, to take Tamara with yourself". Шӱжаремкушкеш, // Акажынкемжым // Вискален, // Пӧлемпокшечэрта (Ivanova, 1976). "Little sister grows up // Sister's boots // being tried, // Passes through the middle of the room". Пасуштокомбайнынкышаже// Шуйнаколхозялвелкыла (Chalaj, 1964). "In the field there were combine's traces, // They spread towards collective farms".

As a rule postpositive and isolated attributes are coordinated with a determined word, for example: Качейоратенгын // Ўдырым, чеверым, // Нуныланогешкерт // Мешаеннимат (Kazakov, 1962). "If a guy fell in love with // Girl, beautiful // Nothing couldinterfere them" (literally). Огынапумландым, тидым, //Огынапукалыкнам (Kazakov, 1951). "Do not give land this, // Do not give our people (literally)". 
Шижатвоктенак // Коммунизмым, эрласым... (Kazakov, 1951). "Do you feel near // Communism, future..."

\subsection{Homogeneous and Inhomogeneous Attributes}

Homogeneous and inhomogeneous attributes are considered in the candidate work of Z. K. Ivanova "Homogeneous parts of the sentence in the Mari language" (1977), in L.P. Vasikova's textbook "The contemporary Mari language. Sintax of the simple sentence" (1987), in V. T. Timofeeva's work "The contemporary Mari language. Sintax of the simple sentence" (1989).

In Z. K. Ivanova's work it is marked: “... parts of the sentence can be homogeneous only when they are independent and connected among themselves by coordinative bond; when they carry out identical syntactic functions towards other part of the sentence and characterize it or are characterized by it in the same way (Ivanova, 1977, p. 5). In our opinion it also can be said about homogeneous attributes, for example: Шарнемсӧрале, чапле, шыжекечым, // Йоча-влакденешолшоуремнам (Chalaj, 1964). "I remember nice, autumn day, // Streets were crowded with children". Кугутӱрван, шемчуриянинспектор, сангажым ӱшкыжлакуптыртен, Пӧтырынмутшымятырколышто (Shketan, 1991). "Inspector with big lips and dark face listened for a long time, wrinkling his forehead, like a bull”. Адакветшыжесылне, чаплепагыт (Kazakov, 1977). "Autumn is wonderful, nice time again".

According to the semantic and syntactic features the homogeneous attributes are equal. They characterize a subject in the same way and specify equal and independent semantic signs of the same subject. Constructions with the homogeneous attributes can be divided into the word combination with the single attribute which will have their own lexical and grammatical meanings: Кумда, ужаролык. "The wide, green meadow". Кумдаолык. "The wide meadow". Ужаролык "The green meadow". Among homogeneous attributes it is possible to swap the components and it does not change the meaning of the statement, for example: Яндар, волгыдопамаш. "The pure, clear spring". Волгыдо, яндарпамаш. "The clear, pure spring".

Z. K. Ivanova wrote that among inhomogeneous attributes there are the attributes which have definite order of the words towards determined word and every previous attribute refers to the determined word with the following attribute, for example: Икйушштӧ, пычкемышноябрьысекужуйӱдымйӱдвоштлумын, эрмартеншечкӱжгытулумвозо (Oraj, 1978). "At one cold night, during the whole dark, November night it was snow, at the morning the snow was a quarter of a yard". Лумпочешлум. Шыжегочвучымомотортеркорно (Oraj, 1978). "The snow was day by day. It was the waiting beautiful toboggan road”. Иквелымтидеплощадыымужарвуянкӥкшӧкӱчеркеавырен... (Shabdar, 1975). "On the one side the territory was blocked with green high stone church..."

L. P. Vasikova defines semantic principles of homogeneity of the attributes: 1) the subject is determined on the one side; 2) the semantic gradation is made; 3 ) the art epithets are homogeneous attributes; 4) they have the same morphological form (Vasikova, 1987).

The author fairly pointed out if morphological form of the attribute differs, it will refer to the group of the inhomogeneous attributes (Timofeeva, 1989).

Coming to the conclusion we can notice that lines of the homogeneous attributes include dependent components, they are equal semantically and syntactically. At the same time homogeneous attributes are connected with each other by coordinated bond and they are subordinated to one main word. Inhomogeneous attributes are unequal semantically and syntactically. Every inhomogeneous attribute defines the previous word and in a close connection with each other they are subordinated to the main word of some inhomogeneous attributes.

\section{Discussions}

In Mari linguistics there are no separate works which are devoted to expanded attribute, some remarks are made in the works of Pengitov (1961, p. 119), Vasikova (1987), Timofeeva (1989). In the dictionary of the linguistic terms following definition of the expanded and not expanded is given: "The expanded parts of the sentence are members of the sentence, having dependant words..." Not expanded parts of the sentence do not have explicative (coordinated, governed, paratactic) words are referred. Not only parts of the sentence an autonomous words but parts of the sentence as not divided word combinations belong to not expanded expression" (SLT, 1972).

In the Mari linguistics M. P. Chkhaidze was the first who wrote about the isolation of the attribute (Chkhaidze, 1941). Describing this phenomena he noticed next moments: according to division of the words into parts of the sentence such attributes can be separated which are adjectives and participles. He wrote that the expanded attributes with dependant words were usually segregated. The author fairly gives the name as participial phrase to the isolated expanded participle with the dependant word. The condition of the isolation of the attribute in the 
role of the adjective and participle is referred to using it after determined word. To confirm his words M. P. Chkhaidze gave the example:Капкайымализипий, оштӱсан, лӧзмӧнпунан, ваштарешемкудаллекте. "Out of the gate a little dog white, shaggy ran towards me" (Chkhaidze, 1941).

N. T. Pengitov gave some comments about isolated attributes in his works (Pengitov, 1961).

In the works of Vasikova (1987) and Timofeeva (1989) isolated attributes were detailed analyzed. Isolated attributes were distinguished into special kind in the works of these researchers. In our opinion authors correctly named cases and conditions of the isolation. Vasikova wrote that attributes are isolated when 1) they take place after the determined word; 2) attributes are connected with personal and attributive pronouns; 3) they have adding adverbial meaning; 4) there is another word between the attribute and the determined word; 5) the attribute and determined word are separated from each other (Vasikova, 1978).

Timofeeva noticed that attribute in the role of the adjective, participle, participle phrase are isolated in the case of having place after the determined word and gave example: Айдеме, пашашкушшо, илышынсаймогыржымпала (Тимофеева, 1989). "Man, having grown up at the work, knows good sides of the life".

According to the position of the determined word attributes are divided into postpositive and prepositive ones. In the dictionary of the linguistics terms preposition is defined as "putting one of two connected elements before others", and on other side postposition is "putting one of the two connected elements before others" (SLT, 1990).

In the Mari language prepositive and postpositive attributes have not been distinguished into separate group yet. In our opinion, it is possible to do in the Mari language.

According to coordination with determined word, we consider that in the Mari language attributes can be divided into coordinated and not coordinated. In the Mari language prepositive attributes are defined as not coordinated ones and postpositive and isolated attributes are considered as coordinated with form of the main word. Coordination of the postpositive and isolated attributes were written by Chkhaidze (1941), Pengitov (1961), Kangasmaa-Minn (1969), Alhoniemi (1983), Galkin (1986), Vasikova (1987), Timofeeva (1989).

The Finnish investigator of the Mari language Kangasmaa-Minn analyzed materials of the Mari texts which were collected by Beke, Regulus, Porkka and Levy. She gave examples of the coordination in the attributive word combinations. The attribute is similized to the form of the determined word and it can be expressed by 1) noun, for example:jenənəm tsonəm nalən, "he took soul of the man" (Kangasmaa-Minn, 1969); 2) adjective, for example: soltaktunalešumsurtumštas; "solder began to build new house "(Kangasmaa-Minn, 1959); 3) pronoun, for example:: mənəməmküoksamšoləštən? "Who stole my money?" (Kangasmaa-Minn, 1959)

A. Alhoniemi found out examples of coordination of the adjective and participle with determined word in the case during studying of the rich material of $E$. Beke, for example: me koləšmjəm kondəšna "we brought a death man "adakkutšüšklüšüm jəm pop üzən toleə "The pope brought six more killers " (Alhoniemi, 1983). In Y. V. Anduganov's work "To the history of the coordination on the level of the form of the words in the Finno-Ugric languages" the opinion was suggested that coordination between secondary parts of the sentencewith subordinating syntactic bond, especially between attributive ties existed in the Proto-Uralic language. The scientist wrote that such coordination was compulsory and there is no doubt among scientists. But in his work Y. V. Anduganovmade the right scientific assumption that in the Proto-Uralic language regressive coordination (coordination between parts of the construction such as attribute-determined word) was widespread" (Anduganov, 1985). Examples, given by scientists, are persuasive that in the Proto-Uralic language regressive coordination was used between components of the attributive group.

The homogeneous and inhomogeneous attributes are considered in Ivanova's candidate work "The homogeneous parts of the sentence in the Mari language" (1977), in Vasikova's textbook "The contemporary Mari language. The simple sentence of the Syntax" (1987), in Timofeeva's work "The contemporary Mari language. The simple sentence of the Syntax".

\section{Conclusion}

During investigation we came to the conclusion that according to different signs attributes are divided into five kinds in the contemporary Mari literal language.

In the Mari language the expanded attributes have the dependantexplicativeword and not expanded ones do not have them. In the Mari language not expanded attributes more often take place.

According to the isolation in the sentence the attributes are divided into isolated and not isolated. In the Mari language the isolated attributes are expressed by adjectives, participle, participle phrase and they take place in 
the postposition to the determined word and they can be separated by other words from it

Before the determined word the attributes are prepositive ones and when they take place after the main word are postpositive ones. The preposition of the attributes is a norm for the Mari language. In the postposition there are the isolated attributes and the attributes in the inversion.

In the Mari language there are coordinated and not coordinated attributes. The coordinated attributes with the main word are the postpositive and isolated attributes. The components of the attributive construction are connected with constructions of possessive relations with help of not full coordination.

According to presence of two or more attributes with different or similar meaning or morphological forms at the determined word homogeneous and inhomogeneous attributes are defined. Components of the homogeneous attributes are connected with each other by the coordinative bond on the one side and they are subordinated to the main word on the side, they are equal semantically and morphologically.

In the line of the inhomogeneousattribute every subsequent attribute explains previous one. All components of such line make one closely connected structure of the syntactic unit semantically.

\section{References}

Alhoniemi, A. (1983). Über die Kasuskongruenz von Adjektiv und Partizip in den tscheremissischen Dialekten (NyK 85, S. 281-289). Budapest.

Anduganov, U. V. (1985). Mut ale mutsochetanij? Tunyktyshylanpolysh (p. 157).

Chalaj, V. (1964). Peledshetukymemlan: Pochelamut-vlak (p. 44). Yoshkar-Ola: Marijknigaizdatelstve.

Chavajn, S. G. (1980). Vozymyzho 3 tom dene savyktaltesh: Poezij, proza (T. 3, p. 318). Yoshkar-Ola: Marijknigaizdatelstve.

Chavajn, S. G. (1981). Vozymyzho 3 tom dene savyktaltesh: Pjesa-vlak. Elnet roman (T. 3, p. 428). Yoshkar-Ola: Marijknigaizdatelstve.

Chkhaidze, M. P. (1941). SyntaksisLugovo-Vostochnogomarijskogojazyka (p. 156). M: Uchpedgiz.

CLT. (1972). The dictionary of linguistic terms (p. 300). M: The Soviet encyclopedia.

Columb, V. (1965). Ere choyeshtashchoneshtash. Pochelamutsbornik (p. 180). Yoshkar-Ola: Marijknigaizdatel'stve.

Columb, V. (1972). Porylyk: Pochelamut-Vlak (p. 144). Yoshkar-Ola: Marijknigaizdatelstve.

Galkin, I. S. (1986). Marijjylmynistorijgrammatikyzhe—Morphlogij da syntaxis: Tunemmekniga (p. 123). Yoshkar-Ola.

Ivanov, A. (1976). Kechanerdene-Pochelamut (p.55). Yoshkar-Ola: Knigamlukshomarijizdatelstve.

Ivanov, Z. T. (1977). Odnorodnyjechlenypredlozhenija v marijskomjazyke: Avtoref. candidate work (p. 17).

Kangasmaa-Minn, E. (1966). The Syntactical Distribution of the Cheremis Genitive. Turku: Societe Finno-Ougrienne.

Kazakov, M. (1951). Poezij (p. 302). Yoshkar-Ola: Margosizdat.

Kazakov, M. (1962). Shÿmbelmlandem-Pochelamut-Vlak (p. 81). Yoshkar-Ola: Margosizdat.

Kazakov, M. (1968). Shÿmtenyz (p. 140). Yoshkar-Ola: Margosizdat.

Oraj, D. (1978). Tÿtyravosht (p. 236). Yoshkar-Ola.

Pengitov, N. T. (1961). Porjadokslov v predlozhenii v Marijskomjazyke Trudy MarNII. Questions of language, the literature and folklore, 6, 113-123.

Pengitov, N. T. (1982). Marijjylmekniga (p. 160). Yoshkar-Ola: Marijknigaizdatelstve.

Peshkovsky, A. M. (1956). Russian Syntax in scientific investigation (p. 511). M: Uchpedgiz.

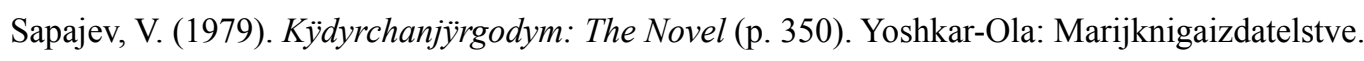

Savi, V. (1978). Erykmuro (p. 168). Yoshkar-Ola: Marijknigaizdatelstve.

Shabdar, O. (1975). Ydramashkorno (p.223). Yoshkar-Ola: Marijknigaizdatelstve.

Shketan, M. (1991). Kum tom dene savyktaltesh: roman, ojlymash, povest, ocherk, feletonthe, novelle, statja, serysh-vlak (T. 3, p. 623). Yoshkar-Ola: Marijknigaizdatelstve. 
Timofeeva, V. T. (1987). Kyzytsemarijjylme-Prostojpredlozhenijsintaksis: Tunyktyshylanpolysh (p. 120). Yoshkar-Ola.

Vasikova, L. P. (1987). Kyzytsemarijjylme-Prostojpredlozhenijsintaksis: Tunyktyshylanpolysh (p. 144).

Vasilev, V. M. (1919). Zapiskipogrammatikejazykanarodamari: Materialypoetimologii I syntaxisu (p. 80). Kazan.

\section{Copyrights}

Copyright for this article is retained by the author(s), with first publication rights granted to the journal.

This is an open-access article distributed under the terms and conditions of the Creative Commons Attribution license (http://creativecommons.org/licenses/by/3.0/). 